\title{
FECHAMENTO DE DIASTEMAS: UMA INTEGRAÇÃO ENTRE ORTODONTIA E DENTÍSTICA RESTAURADORA
}

Eduardo Guimarães KUBITSKI; Sergio KUBITSKI; Patricia M. SOUZA; Renato Leite ROSA

Será discutido neste trabalho o relato de caso clínico, em que o paciente F.M., sexo masculino, 20 anos de idade, iniciou o tratamento ortodôntico para correção da falta de vestibularização dos incisivos superiores, distemas entre os caninos e prémolares superiores e desvio de linha média. $O$ tratamento ortodôntico foi concluído em 9 meses e como conseqüência, houve ganho de espaço na arcada superior e abertura de diastemas entre os incisivos, fato qual já fazia parte do planejamento do caso. Os espaços eram de aproximadamente $1,5 \mathrm{~mm}$ entre os laterais e caninos superiores. O paciente foi encaminhado para o curso de especialização em Dentística Restauradora para que fosse realizado o procedimento restaurador estético. Foi realizado um mock up, e a partir deste ensaio os diastemas foram fechados com resinas nanoparticuladas para que fosse devolvida a proporcionalidade do sorriso. Com isso, a integração dentística/ ortodontia pode devolver a harmonia de forma rápida e conservadora, garantindo ótimos resultados e com a satisfação tanto do paciente quanto dos profissionais envolvidos no trabalho. 